Francesco TRUPIA*

\title{
DEBUNKING 'THE GREAT EQUALISER' DISCOURSE: MINORITY PERSPECTIVES FROM BULGARIA AND KOSOVO DURING THE FIRST SHOCKWAVE OF THE COVID-19 PANDEMIC
}

\begin{abstract}
During the first shockwave of the Covid-19 pandemic, the risk of infection was inaccurately touted as 'the great equaliser'. However, the virus' rapid spread and the state of emergency accelerated the magnitude of pre-existing inequalities by taking a heavy toll on already marginalised, exploited and extremely poor segments of societies. Focussing on sub-national contexts in Bulgaria and Kosovo, this article demonstrates how Bulgarian Roma and Kosovo Serbs were not only hit the hardest by the introduction of ad hoc lockdowns and curfews, respectively, but also how disciplinary mechanisms of control and surveillance were embedded in public methods and cultural policies of scapegoating and ascribing images of societal irresponsibility and backwardness upon these two minority groups.
\end{abstract}

Keywords: Bulgaria; Kosovo; minority groups; pandemic; ad hoc restrictions; stigmatisation

\section{Introduction}

After the World Health Organisation (WHO) declared a pandemic on 11 March 2020, the diffusion of the SARS-Cov-2 was inaccurately touted as 'the great equaliser'. As the virus would easily transcend traditional boundaries such as wealth, fame, prestige and age (Mein, 2020: 2439), the outburst of the pandemic was foreseen as a ticking bomb for public healthcare systems. On the geopolitical level, several pundits and commentators were quick to conclude that the new epidemiological crisis would definitely tone the populist voices down, thereby delegitimising their rhetoric and hierarchical methods of doing politics. This new conjuncture suggested that prominent and impartial experts and scholars would successfully oppose such populisms and their demagogues in a state of emergency (Katsambekis and Stavrakakis, 2020: 3). Yet, immediately the reality appeared far from ideal

* Francesco Trupia, Postdoctoral Fellow, University Centre of Excellence Interacting Minds, Societies and Environment (IMSErt), Nicolaus Copernicus University, Toruń, Poland.

DOI: 10.51936/tip.58.specialissue.616-631 
since SARS-CoV-2 began to spread and infect thousands of people around the world.

Although it was expected to exclusively have a major impact on healthcare systems, the pandemic overwhelmed the public health sphere and affected all aspects of people's everyday life (Trupia and Madhi, 2021: 10). Particularly contested since the initial shockwave of the Covid-19 pandemic, the 'great equaliser discourse' took on a new form. Government officials as well as media outlets and a list of notable figures began to warn about the serious impacts the Covid-19 pandemic would bring to all aspects of personal, social and even political life (Abraham, 2020). It was therefore recognised and reported that the pandemic would soon impinge much more strongly on domestic politics and social trends related to how this state of emergency was being politically handled (Filipova et al., 2020: 8-9).

Amid the highly dynamic and still unfolding epidemiological crisis, this article aims to further debunk the pro toto discourse concerning the SARSCoV-2 infection rate by narrowing it down to Bulgaria and Kosovo's subnational contexts ${ }^{1}$. Within these two Balkan countries, neither the infection rate, fatality cases, nor economic impacts constitute the main subject of investigation. On the contrary, this article looks precisely at two main non-majority communities - Bulgarian Roma and Kosovo Serbs - with the sole intent of shedding light on each community's views of reality (Given, 2008) arising from the disruption created by the first phase of the pandemic. From this emic perspective, it is argued that the SARS-CoV-2 virus did not act as a 'great equaliser' in the societies under study. Conversely, the virus is acting as a great accelerator by deepening and exacerbating the phenomenon of the systematic marginalisation that existed already before March 2020. Namely, an attempt is made to further debunk 'the great equaliser' discourse by casting a spotlight on how the official safety measures imposed to deal with the spread of SARS-CoV-2 and minimising the risk of contagion have not only deepened the many inequalities, but also subtly reinforced images of a health threat, civil irresponsibility, a lack of deservedness, and backwardness upon alreadymarginalised segments of societies (Minority Rights Group International, 2020: 8). Since ethnic Roma and Serbs are respectively largely understood as the main 'ethnic other' in Bulgaria and Kosovo, the decision to look at ethnicity rather than other cultural identifiers stems from the assumption that ethnicity per se played a central role in both Balkan countries even before the pandemic began. While the Serbian minority is often depicted through the historical lens of Slobodan Milosevićs repression and post-1999 disloyalty, Bulgarian Roma are stigmatised in the public wider by being negatively

1 This designation is without prejudice to the status of Kosovo's declaration of independence and in line with UNSCR 1244 and the ICJ Opinion. 
identified as the main spoilers of the allocation of public resources and other social benefits. During the first shockwave, Bulgarian Roma, who tend to identify themselves as either Bulgarian or Turkish so as to avoid overwhelming stigmatisation (Institute Open Society, 2008: 13; Trupia, 2019), were primarily targeted. Kosovo Serbs, who instead had inconspicuously developed some constructive strategies and pragmatic ideas of collaboration and inclusion in Kosovo's legal and institutional framework (Trupia and Stephanie Schwandner-Sievers, 2019), were hit the hardest by the local curfews.

In this regard, this article seeks to help advance the state-of-the-art literature by debunking the myth of 'the great equaliser' and looking at the experiences of two minority groups from within their national contexts. While providing an alternative and critical analysis of the pandemic's implications, this article does not intend to estimate the impact of ad hoc mechanisms of surveillance and local curfews during the first shockwave (March-June 2020). Conversely, it raises the question of how the introduction of the state of emergency in Bulgaria and Kosovo led to ad hoc safety and security measures against certain segments of both societies. Further, to what extent were these mechanisms of control as well as the implementation of surveillance already embedded in certain political methods and 618 cultural practices of discriminating and scapegoating even before the epidemiological crisis?

\section{Researching Minority Groups during a Pandemic}

From March 2020 onwards, the distinct vulnerabilities of migrant workers and ethnic minorities have played a critical role (Wishart, 2020: 41). A greater proportion of racial and ethnic minority groups remains both at a higher risk of contracting SARS-CoV-2 and suffering worse outcomes due to longstanding societal inequalities (Mein, 2020: 2440). As demonstrated worldwide, a large variety of social determinants of health - including poverty, living conditions, gender, race, ethnicity, healthcare systems, GDP per capita, education, trust toward political authorities (Akeel and Khoj, 2020: 848) - have interacted peculiarly to spread SARS-CoV-2 faster and exacerbate social disparities. The Covid-19 crisis has already imposed a heavy toll on minority groups, showing how the risk calculation of contagion has profoundly and unevenly impacted both morbidity and mortality (Abrams and Szefler, 2020: 659). Counter to the expected 'equalising takeaways', the state of emergency has definitely reopened a central discourse regarding the magnitude of disproportionate and adverse impacts on specific segments of societies (OHCHR, 2020: 1). Within sub-national groups as well as ethnic and religious groups, women are more likely to have been affected and challenged than men due to gender-based discrimination (Naseva, 2020: 93). 
Unlike the staggeringly high mortality rates among the Black and other minority populations in the United States and the United Kingdom, similar issues have either been overlooked or less discussed in Central and Eastern Europe (Wishart, 2020: 41). In this region, those states that began to rapidly enact lockdown measures even before a significant massive spread of the virus (Walker and Smith, 2020), such as Bulgaria in March 2020, have de facto further burdened marginalised groups already worst affected by the introduction of a state of emergency (Willis, 2020: 11). Ironically, the virus was neither acting alone nor spreading equally among all segments of society (Matković and Stubbs, 2020), leaving little doubt that both the spread and diffusion of SARS-CoV-2 was 'a great equaliser'. Moreover, Southeast Europe's strongmen in power, such as Aleksandar Vučić in Serbia among others, rapidly captured democratic institutions and achieved almost unlimited power on the national level (BiEPAG, 2020: 9). Foreign authoritarianisms in Russia, China and Turkey also continued to promote their activities within the region through the vested interests of support and solidarity in a time of crisis. At the grassroots level, a new wave of (ethno-)nationalist sentiments refocused on the 'ethnic other', revitalising a ubiquitous history of ethnic nationalism and nationalist polarisation. In these circumstances, the new rifts have not only increased the distance between the 'people' and the 'elites', or between those who govern and the governed (Lokot and Avakyan, 2020: 2-4), but reopened old wounds that keep on reappearing when humanity is in its most vulnerable state (Naseva, 2020: 93).

Given the above, the following sections not only assist in further debunking 'the great equaliser' discourse concerning the infection rate in Bulgaria and Kosovo. Instead, they serve to counter taken-for-granted assumptions with regard to the risk of being exposed to infection and the spread of SARSCoV-2 in order to demonstrate how they were later subtly verbalised to justify safety and security measures bearing upon pre-existing public policies and cultural practices involving minority groups in both countries.

In terms of methodology, it is noted that the travel restrictions and lack of access to fieldwork sites have not come without a cost. Hence, a caveat must be addressed. Bearing in mind the highly dynamic development of the state of emergency which is still unfolding and in place, first-hand data could not be collected. Likewise, a participation-observation strategy was not recommended for safety reasons on the ground. Concerned with avoiding the risk of de-emphasising the methodological process and potentially diminishing its strength with respect to qualitative research, this study adopts an ethnographic sensibility (Simmons and Smith, 2017) through the lens of intersectionality. While this tandem cannot entirely overcome the mentioned limitations, it can partly shed light on the structural challenges and already-embedded cultural and political methods of scapegoating in 
Bulgaria and Kosovo prior to the start of the pandemic. In doing so, such a twofold perspective helps to fill the vacuum of uncollected data and unconstructed knowledge from the ground, attaining the study's research objectives regardless. Ethnographic sensibility is used here as a way of knowing rather than a research instrument for collecting information and later writing about it (Pader, 2006; Schatz, 2009). Since ethnographic sensibility does not require long-term immersion in field sites and participant-observation as exclusively as methods typically used by anthropologists (Simmons and Smith, 2017: 126), such an approach is not only a kind of intellectual effort aimed at elaborating a 'thick description' of and about humanity in a context subjected to law (Geertz, 1973: 6). On the contrary, it is also a way for becoming more responsibly aware of deep inequalities and for better understanding those social forces that cause suffering and, generally, bring the perpetually pulled beyond the limits of their own taken-for-granted world (McGranahan, 2018: 3-7).

This article uses the mentioned methodological toolkit to illuminate those multiple forms of inequality that were affecting certain segments of society prior to March 2020. Since Bulgaria and Kosovo entail two diverse national contexts along with different historical and socio-political trajecto620 ries of power hierarchies and historical backgrounds, this emic approach does not aim here to exert control over a number of identified variables (Simmons, 2017: 127). Conversely, it aims to examine the meaning-making practices of Covid-19 outcomes in the development of humanitarian settings through a critical analysis of power-oriented subtle public decisions that have come to ossify societal hierarchies rather than protecting equality amongst the most vulnerable communities. In conducting such a critical review of both effects and consequences of the pandemic among ethnic minority groups, this methodological approach is therefore able to show how the high level of pre-existing inequalities has not only persisted, but that it has also deepened different power hierarchies and forms of oppressions in lived experiences (Lokot and Avakyan, 2020: 4).

The choice to explore the Covid-19 pandemic's impact on two different ethnic minority groups through the lens of intersectionality, assumes that social groups are not homogenous. In fact, following Lokot and Avakyan's argument, intersecting intra-group dynamics are largely noteworthy since they are currently playing a central, paramount role in shaping social conditions and lived experiences (2020: 2-3). In this respect, while intersectionality helps with understanding how pre-existing forms of subordination and exclusion were taken further by subtle mechanisms of control and surveillance, the ethnographic sensibility will assist in grasping the reality on the ground. This points to an interlinked consideration while researching minority groups at a time of travel restrictions and denied access to 
fieldwork settings. When exploring the Covid-19 pandemic according to some indicators of health or determinants (e.g. sex, ethnicity, race, religion, language), data disaggregation is a major concern. Hence, it is necessary to contextualise to ensure an adequate analysis based on data that are available yet not accompanied by any explanation of the social factors that may create 'spikes' in particular indicators among minorities or indigenous people (Minority Rights Group International, 2020: 5).

Therefore, this article relies on a number of briefings and open-access resources from media outlets, civil society organisations and policy guidelines that have been designed to ensure critical considerations embedded in Covid-19 responses within the development and humanitarian settings. Moreover, previously acquired information and knowledge constructed from participation-observation fieldwork will be employed as they were developed in research dealing with the identity negotiations of Kosovo Serbs (Trupia, 2019) and Bulgarian Romani (Trupia, 2018: 122) in their places of residence with regard to security dilemmas and everyday life.

\section{Bulgarian Roma: fewer cases, stricter measures?}

Since March 2020, the pandemic in Bulgaria has not simply exacerbated domestic tensions with the most impoverished minority group in the country - Bulgarian Roma, but also heightened the ongoing phenomena of marginalisation, exploitative labour regulations and systematic forms of racism which ethnic Roma communities have been systematically exposed and subjected to. Exceeding the reasonable suspicion that extremely poor living and sanitary conditions of the Roma minority might increase the infection rate, the Bulgarian authorities decided to implement ad hoc security actions. Roma neighbourhoods were then heavily policed and subjected to mandatory quarantine (Minority Rights Group International, 2020: 8). Despite the fact that Covid-19 cases were not properly mapped and identified in Roma neighbourhoods due to the lack of screening and mass testing, lockdowns were imposed as a precautionary measure to handle the spread of the SARS-CoV-2 and mitigate the risk of contagion among all Bulgarians.

In line with such decisions, local authorities implemented the lockdowns through the heavy patrolling of the police around the Roma neighbourhoods of Fakulteta and Filipovtsi in the capital Sofia as well as in the small towns of Peshtera and Brestovitsa. Likewise, Roma members residing in the Rayna Knyaginya and Iztok neighbourhoods, respectively in Yambol and Kyustendil, were forced into lockdown. As a result, a population of some 10,000 Bulgarian citizens of Roma origin was cut off the job market (European Union Agency for Fundamental Rights, 2020: 11), thereby disproportionately affecting the majority of Roma workers, particularly 
women engaged in local markets as street vendors and fruit pickers, or involved in the construction or recycling sectors. At the same time, the lockdown measures brought to the surface a series of structural challenges with which Bulgarian Romani have historically struggled. Among others, their extremely poor living conditions, limited spaces and substandard housing did not permit Roma communities to comply with any basic recommendations, such as social distancing, isolation and hygiene. Prior to implementing the lockdowns and curfews in Roma neighbourhoods, Bulgarian authorities did not take account of the deeply embedded socio-economic inequalities and structural challenges that could have spread the SARS-CoV-2 virus faster rather than mitigating its impact among Roma communities and protecting them at the highest level. In other words, the pre-existing issues of extremely poor living environments, the lack of running water and basic sanitation were systematically overlooked within Roma-majority clusters. All of these circumstances had yet another impact on Bulgarian Roma. The neighbourhood lockdowns not only distorted the bigger picture of the calculation of risks of exposure and contagion rates, but in essence also created a series of locally-nuanced microcosms where exclusion from the majoritarian cultural system widened. In the time period in which Roma neighbourhoods were cordoned off and patrolled by the police, the government did not apply any other specific measures. Paradoxically, albeit unsurprisingly, in early June the Bulgarian health minister allowed fans to attend football matches at the stadium, sparking controversies in the following weeks (Krasimirov, 2020).

Also considering the scarce access to Covid-19 screening and testing facilities across Bulgaria, lockdowns and police patrolling around Roma neighbourhoods did not aim to tackle the many pre-existing structural deficiencies and challenges, nor to protect low-income or at-risk communities at a time of pandemic. On the contrary, such forms of protection and mechanisms of control misused the statistics and information regarding the most vulnerable groups in Bulgaria by shifting people's attention away from a state of emergency to a state of alert. In so doing, it is more likely that Bulgarian institutions conveyed a subtler message of societal mistrust toward the Roma minority on all levels of everyday life, leaving much greater room for certain forms of scapegoating in the broader public.

To better understand how the popular images of backwardness and irresponsibility were reinforced upon the Roma minority, one simply needs to recall the pictures of drones with thermal sensors flying above the Roma neighbourhood in Burgas to detect residents with high temperature, or those of a plane spraying disinfectant on Roma houses and streets in Yambol (European Union Agency for Fundamental Rights, 2020: 12). When tensions between Roma living in locked-up neighbourhoods and the police have occasionally erupted into street violence, the latter has rapidly reinforced 
the widespread stigma of 'Roma crime'. Hence, the introduction of restrictive measures in Roma neighbourhoods was accompanied by increasingly hostile anti-Roma rhetoric, which was not only the result of subtler mechanisms of control and surveillance that had scapegoated Roma members for spreading the virus, but also of the frequently stoked vernacular rhetoric that certain politicians often expressed. Before the pandemic, Roma members had already been depicted as the leading collective threat for the general population generally and for exploiting the public healthcare system in particular (Minority Rights Group International, 2020: 8).

In fact, under the guise of diversity and culture, it did not take long for the Bulgarian National Movement - VMRO - a political party member of the former ruling coalition - to subtly call for Roma 'ghettos' to be locked down. Arguing that they could turn out to be real nests of contagion because of their poor living conditions and low levels of hygiene (European Union Agency for Fundamental Rights, 2020: 27), VMRO's approach to the 'Roma issue' did not come out of the blue, nor was it presented as an immediate protection policy. In February 2019, the nationalist party had already introduced its proposal for "Changes to the Integration Policy of Gypsy (Roma) members of the Republic of Bulgaria and the Implementation Measures" to discuss certain major concerns amongst Bulgarian society. The underlying policy concept immediately triggered a storm of scholarly critiques and protests in civil society since the idea of mobilising potential electors around the much-debated 'Roma issue' appeared to be the primary objective of implementing public policies in Bulgaria. Political speculation and general suspicion regarding the timing of proposing the concept were immediately raised. On one hand, it was legitimate to consider VMRO's attempt to intentionally inflame the wider public, made prior to both the European Union elections in May 2019 and the local elections held across the country and in the capital Sofia, a political strategy. Yet, on the other hand, this step not only showed a timely effort to embrace complexity in the historical analysis of nativism in Bulgaria, but also the lasting effect in Bulgarian society regardless.

Moreover, the pandemic has added to the difficulties facing the freedom of speech in Bulgaria (Center for the Study of Democracy and KonradAdenauer-Stiftung, 2020: 23). Within a country which not all consider possesses a pluralist media sector, Roma communities suffered more discrimination than other social groups (Freedom House, 2020). Many civil society organisations and international media outlets have nevertheless reported and covered events in Roma-majority neighbourhoods. According to them, introduction of a state of emergency left the Roma minority more deeply isolated while coping with two acute issues: remote education after the mass closure of schools across the country, and the shrinking space for freedom of speech (Georgieva, 2020). In that respect, although the 
Ministry of Education and Science provided and concluded agreements with mobile operators to provide an Internet connection to students at preferential prices, no information is publicly available on the share of Roma children who benefited from these measures (European Union Agency for Fundamental Rights, 2020: 14). Many journalists also warned about attempts to misuse Article 326 of the Penalty $\operatorname{Code}^{2}$ even in the absence of a proper state of emergency. The core function of this provision was to penalise those responsible for fake bomb alerts and people who abuse police, fire brigade, and ambulance workers by calling 112 without actually needing their assistance.

The latter could have an impact on those Roma communities obliged to live within their cordoned-off places of residence, where tensions were on the rise after March 2020 and violence against the police erupted due to the apparently unmotivated decision to lock the neighbourhood down. While the Covid-19 pandemic has given an opportunity for the broader application of Article 326, the latter seems to have turned a declared "state of emergency" for all of society into the context of a much more specific "state of alert" due to already-known major concerns.

\section{Kosovo Serbs: Marginality on the Margins}

While mass-scale protests in Bulgaria repeatedly called for the leading government cabinet to resign, yet without any results, Kosovo is the best example in Southeast Europe for investigating how the epidemiological crisis created a perfect storm to oust the ruling government coalition.

In this regard, although Kosovo was not only the first case of a newly appointed national government being toppled in a no-confidence vote during the Covid-19 pandemic, it also exacerbated other well-known domestic issues. For instance, while the state of emergency would have finalised an agreement with Serbia and Kosovo under the auspices and facilitation of the US administration, the lack of any broader democratic legitimacy and the potential involvement of a contentious "land swap deal" 3 contributed to the process stalling (BiEPAG, 2020: 10).

2 Article 326 (Last amendment, SG No. 26/2010)(1) (Former text art. 326, SG No. 26/2010) (2)(New, SG No. 26/2010) states that a person transmitting over the radio, by telephone or in some other way false calls or misleading signals for help, an accident or alarm, shall be punished by deprivation of liberty for up to 2 years. If significant harmful consequences result from the commitment of a criminal act under paragraph (1), the sentence is imprisonment of up to 5 years and a fine of 500 to 2,000 levs.

3 By redrawing boundary territories along ethno-majoritarian lines, namely, by compromising about $10 \%$ of Kosovo territory through a territorial exchange of the Serb-majority municipalities in North Kosovo and its population of 50,000 citizens with the Albanian-majority municipalities of Bujanovac and Preševo in the southernmost Serbia, Belgrade and Pristina would have finalised the two-decade process of reconcili ation. 
In a political crescendo, the pandemic again put the already-challenging dynamics of the Serbian community and other minority groups in the spotlight. The Kosovar Government's communication with non-majority communities was largely ineffective since it made room for an informal vacuum among non-majority groups (Aktiv, 2020: 3). Healthcare protocols dominated discussions, yet without accounting for vulnerable groups, who rarely received attention or resources. The representation of marginalised groups was not routinely ensured while planning and monitoring the evaluation of the pandemic response (Matković and Stubbs, 2020: 11). Among Kosovo Serbs, the state of emergency not only entailed different restrictions than in other countries, but it deepened the structural challenges after the mass closure of schools (Trupia and Madhi, 2021: 19), businesses etc. Nor did it divert from measures of social distancing and curfews, including bans on gatherings in public spaces (Simic, 2020). On the contrary, it rapidly brought to the surface great scepticism regarding the official information among ethnic Serbs, whose mistrust in the government of Kosovo increased, especially with regard to the information about contagion and the death toll (Aktiv, 2020: 3-11). This likely came to deepen the 2-year standoff in the EU-facilitated Brussels Dialogue between Belgrade and Pristina. On the grassroots level, while Kosovo Serbs are indeed nowadays shown to be unable to come to terms with their past, Kosovo Albanians cannot fully reconcile with the Serbs (European Western Balkans, 2020). Still, the 2018 'land swap' proposal - immediately criticised by the European Union as setting a dangerous precedent for the region - did not help to smooth the 'Brussels Dialogue'. On one hand, those in favour, chiefly on the Serbian side and most notably high government officials in Serbia, do very little for the Kosovo Serbs. On the other hand, the proposal for a "border correction" remains not entirely rebutted in light of the poor negotiation results achieved (Tadić, 2019: 256; Dragojlo and Bami, 2020), leaving the Serbian minority in a struggle with discriminatory barriers and in-between two competing regimes for the citizen, one subjected to Pristina and the other to Belgrade (Trupia, 2019). In this respect, the epidemiological crisis placed Kosovo Serbs in a much worse position within the already-marginalised areas of the country. During the first shockwave, ethnic Serbs had to navigate between the prevention and control mechanisms of the Serbianbacked local authorities and Kosovo's authorities. In an attempt to comply with both central authorities, Kosovo Serbs' uniquely difficult position did not only reveale a series of well-known major concerns of a community straddled between two governments but is also shone a strong light on the everyday identity and security dilemmas they constantly face in light of the uncoordinated and often conflicting and competing citizen regimes. 
At the same time, the pandemic is expected to negatively impact Kosovo's economy on both the national and local levels. Municipalities will likely be more affected with respect to their budgeting due to the reduction of general grants, the decrease in own revenues and lack of investment from the central level (GAP, 2020: 6). The much-debated Association of Serb Municipalities, which had largely lost its influence on the political agenda after having been declared unconstitutional by the Constitutional Court in $2015^{4}$, would potentially implement legislative and constitutional norms that may otherwise shape basic protection in a time of economic uncertainty (Aktiv, 2020: 8-9). This vacuum may also work to Kosovo's institutions advantage after their effort to spend millions of euros to pay the salaries of former members of the Serbian Civil Protection Corps without it being properly integrated into state structures (Simic, 2020).

All of the above underscores how far apart the Serbian minority remains from Kosovo's institutional system on all levels. Kosovo Serbs were deprived of travelling across the ten Serb-dominated municipalities. While it was easier for those residing in the northern areas due to their geographical proximity with the Republic of Serbia, for those Serbs living in the central and southern rural areas of Kosovo the pandemic simply added to their margin626 alisation. While prior to the pandemic, the EU-facilitated Brussels Dialogue aspired to 'disenclave' Kosovo Serb-majority areas (Fort, 2018), the epidemiological crisis and implementation of local curfews opened the door to some sort of an impunity environment. The NGO Aktiv-led Rapid Response Civic Group reported new cases of skirmishes with clear ethnic connotations against non-majority communities, where a series of crimes had threatened the human security of individual Serbs and their communities across Kosovo. In the timeframe of March to June 2020, a total of 30 arsons, thefts, physical attacks and acts of vandalism and graffiti were reported against Serb minority members while their property proved to be an easy target. Particularly concerning were the large numbers of attacks reported on the properties of returnees (RRCG, 2020). Regardless of the difficult conditions and circumstances, Kosovo institutions failed to report such acts of hostility and vandalism and thus the vast majority of these incidents have not been prosecuted.

4 It is worth noting that the A/CSM was deemed potentially unconstitutional by the Constitutional Court of Kosovo in a decision from 23 December (Judgement on Case No. KO 130/15) despite being envisaged by Articles 4-6 of the Brussels Agreement which state that the Association/Community should have a "full overview" of key areas of public life in Serb-majority communities (Aktiv, 2020: 2-3). 


\section{Conclusion}

With respect to the two locally nuanced cases and the timeframe, this research article reveals how Roma communities in Bulgaria have been heavily targeted by ad hoc mechanisms of surveillance subtly implemented in the name of human security for all Bulgarians. In the same vein, it shows how the introduction of curfews across Kosovo deepened the structural challenges facing non-majority communities, particularly ethnic Serbs living in a socio-political limbo already before March 2020.

In both contexts, the pre-existing forms and practices of systematic discrimination and marginalisation are likely to impact state policies and public institutions in their future attempts at ensuring that their national economies recover from the Covid-19 pandemic. In fact, the post-pandemic scenario is best characterised by even tougher historical conditions among those communities hit the hardest (Eberhardtet et al., 2020: 9). Drawing on the issues mentioned above, this article concludes that claiming that the SARS-CoV-2 virus is 'a great equaliser' is not simply inaccurate but misleading, even for predicting scenarios and policies intended to serve the wider public.

As noted, in both Bulgaria and Kosovo the epidemiological crisis has further deteriorated majority-minority relations and worsened already existing spatial issues by deepening and exacerbating divides between (sub-) urban and rural spaces. Moreover, it is clear that since the first shockwave the SARS-Co-2 virus has not spread and infected equally. It has instead been acting as a great accelerator of social disparities, deepening and exacerbating the many determinants that are still being subtly used in the rhetoric of political figures to accuse certain segments of societies of being socially irresponsible and backwards. In Bulgaria and Kosovo, everyday life shows how such stereotypical accusations and messages of social irresponsibility and the inability to display 'decent' comportment in public have been reinforced through the neighbourhood lockdowns and curfews. The latter have not merely discriminated ethnic minority groups, but also revitalised the ubiquitous history of vernacular nationalism and racism.

From a methodological viewpoint, the intersectional analyses in tandem with ethnographic sensibilities reveal the rationale local authorities and central governments have relied on while subtly implementing mechanisms of control and surveillance. The application of an interdisciplinary methodology shows how certain marginalised communities were already struggling prior to March 2020. The Covid-19 pandemic has simply added to the burden on minority groups and forced them to deal with another issue and the worsening situation that has ensued in both the public and private spheres.

This research article moves beyond the ongoing marginalisation and scapegoating of at-risk communities in Southeast Europe, by putting a 
spotlight on how ad hoc mechanisms of surveillance and control can embed methods of doing politics in the near future. If mutual trust had been a major concern with respect to establishing a positive relationship between the State and ordinary citizens/residents prior to the pandemic's start (BiEPAG, 2020: 6), the Covid-19 pandemic may have already caused shortcomings that institutional communication and public policies will be unable to fully address. Between March and June 2020, irrespective of their cause, these shortcomings have not only added to the sense of alienation among Kosovo Serbs and the sense of a priori discrimination among Bulgarian Roma. Namely, they have also shown how certain segments of societies in Southeast Europe began to cope with the pandemic by seeking to learn from previous crises and without relying on the State. In the cases of Bulgarian Roma and Kosovo Serbs, both minority groups were shown to be able to recognise the differing impacts of the pandemic and deal with it in relation to their already-accepted status of subordination and exclusion from the core of society.

The images of cordoned-off Roma neighbourhoods patrolled by the police, or the great underdevelopment and isolation of Kosovo Serbs, did not surprise members of these communities. Ironically, while Western 628 European countries were increasingly concerned about a shortage of agricultural labourers and caregivers for the elderly, Southeast and Eastern European countries were simply not responsive to the evident ethnicitybased system of labour exploitation and unfair recruitment of their countrymen abroad (Crețan and Light, 2020: 3-4). It is worth noting that many workers from Balkan countries (e.g. Bulgarians, Romanians, Albanians) and Central-Eastern Europe (e.g. Poles, Ukrainians) were employed in Germany, Italy, Austria and the UK after the first shockwave. In Eastern and Southeast Europe, governmental failure to address the dilemmas facing nationals who move abroad and suffer from overcrowded housing and poorly-maintained working facilities in their EU host-countries, thereby being at risk of becoming infected with SARS-CoV-2 and further spreading the virus (Wishart, 2020: $44)$, produced a double process of scapegoating and isolation.

To conclude, the cases of Bulgarian Roma and Kosovo Serbs are both valuable while seriously reflecting on the intersection of the future of postpandemic housing and nutrition policies in Southeast Europe and beyond. In fact, it is also essential to highlight how the still unfolding epidemiological crisis suggests the prospect of opportunities to arrive at a new system of values (Dawson and Mellor, 2020:26) for the years and generations to come. First, the current state of emergency seems to provide an opportunity to embrace the complex historical analysis of disparities and inequalities (Slater and Simmons, 2010: 661) - regardless of the regional and societal perspectives taken into consideration. Second, it also seems to potentially 
enhance the fine-tuning of public responses and policies on the local, national and global levels. Despite the expected shortage of first-hand data and participation-observation, ethnographers, sociologists and social scientists might further engage in critical analyses in an attempt to mitigate social determinants, with a particular focus on those marginalised groups living in peripheral and underdeveloped areas where overcrowded home environments and poor healthcare policies and hygiene remain a major concern.

\section{BIBLIOGRAPHY}

Abrams, M. Elissa and Stanley J. Szefler (2020): Covid-19 and the Impact of Social Determinants of Health. The Lancet 8: 659-661.

Akeel, Hatem and Haitham Khoj (2020): Is Education or Real GDP per capita Helped Countries Staying at Home During Covid-19 Pandemic: Cross-Section Evidence? Journal of Entrepreneurship and Sustainability 8 (1): 841-852.

Crețan, Remus and Duncan Light (2020): Covid-19 in Romania: Transnational Labour, Geopolitics, and the Roma 'Outsiders'. Eurasian Geography and Economics 61 (4-5): 559-572.

Dawson, Annabelle and Mary Mellor (2020): The Cost of Care: Rethinking Value in Times of Crisis. Green European Journal 20: 26-32.

Given, M. Lisa (2018): Emic/Etic Distinction. The SAGE Encyclopaedia of Qualitative Research Methods.

Katsambekis, Giorgios and Yannis Stavrakakis (2020): Populism and the Pandemic - A Collaborative Report. POPULISMUS 7 (Special Edition): 1-53.

Lokot, Michelle and Yeva Avakyan (2020): Intersectionality as a Lens to the Covid19 Pandemic: Implications for Sexual and Reproductive Health in Development and Humanitarian Contexts. Sexual and Reproductive Health Matters - More than a Journal 28 (1): 1-4.

Main, A. Stephen (2020): Covid-19 and Health Disparities: The Reality of 'the Great Equalizer'. Journal of General Internal Medicine 35 (8): 2439-2440.

McGranahan, Carole (2018): Ethnography Beyond Method: The Importance of an Ethnographic Sensibility. Sites: New Series 15 (1): 3-7.

Naseva, Gala (2020): The Chasm of Structural Discrimination: Women on the Frontline against Covid-19. Identities: Journal of Politics, Gender and Culture 17 (2-3): 90-93.

Pader, Ellen (2006): Seeing with an Ethnographic Sensibility. In Yanow, Dvora and Schwartz-Shea, Peregrine (eds.), Interpretation and Method: Empirical Research Methods and the Interpretive Turn, 161-175. New York: M. E. Sharpe.

Simmons, S. Erica and Nicholas Rush Smith (2017): Comparison with an Ethnographic Sensibility, 126-130. American Political Science. Cambridge: Cambridge University Press.

Schatz, Edward (2009): Ethnographic Immersion and the Study of Politics. In Schatz, Edward (ed.), Political Ethnography: What Immersion Contributes to the Study of Politics, 1-22. Chicago: University of Chicago Press.

Tadić, Katarina (2019): Understanding the Internal Dialogue on Kosovo in Serbia. In Armakolas, Ioannis, Demjaha, Agon, Elbasani, Arolda and Schwandner- 
Sievers, Stephanie (eds.), Local and International Determinants of Kosovo's Statehood, 239-270. Pristina: Kosovo Foundation for Open Society.

Trupia, Francesco (2019): Idiosyncratic Identity of Muslim Turks and the Romani of Bulgaria: Rethinking Human Security through the Prism of Self-Governing Rights. In Do an, Evinç (ed.) Reinventing Eastern Europe: Imaginaries, Identities and Transformations, 115-130. London: Transnational Press London.

Trupia, Francesco (2019): Good Personhood in Kosovo: A Serbian Perspective from Below. In Armakolas, Ioannis, Demjaha, Agon, Elbasani, Arolda and Schwandner-Sievers, Stephanie (eds.) Local and International Determinants of Kosovo's Statehood, 135-164. Pristina: Kosovo Foundation for Open Society.

Willis, Craig (2020): Economic Effects of the Covid-19 Pandemic on Roma Communities in Albania, Bosnia and Herzegovina, Moldova, Montenegro, North Macedonia, Serbia and Ukraine. European Centre for Minority Issues 122: 1-27.

\section{SOURCES}

Abraham, Yvonne (2020): The Rich and Famous Get the Coronavirus, Too. But It's No Equaliser: The Boston Globe. Accessible at https://www.bostonglobe. com/2020/03/26/metro/rich-famous-get-coronavirus-too-its-no-equalizer/, 26. 3. 2020 .

Coronavirus Pandemic in the EU: Impact on Roma and Travellers. Luxembourg: European Union Agency for Fundamental Rights: August 2020. Accessible at https://fra.europa.eu/en/publication/2020/covid19-rights-impact-september-1, 26. 3. 2020.

Covid-19 Between Reality and Disinformation. Mitrovica: Rapid Response Civic Group - NGO Aktiv: 2020. Accessible at http://ngoaktiv.org/publication/covid19-between-reality-and-disinformation, 26. 3. 2020.

Covid-19 and Minority Rights: Overview and Promising Practices. OHCHR - Office of the United Nations High Commissioner for Human Rights: June 2020. Accessible at https://www.ohchr.org/EN/Issues/Minorities/Pages/COVID19and-minority-rights.aspx, 26. 3. 2020.

Inequality and the Impact of Covid-19: How Discrimination Is Shaping the Experiences of Minorities and Indigenous Peoples during the Pandemic. Minority Rights Group International: September 2020. Accessible at https:// minorityrights.org/publications/covid-briefing/, 26. 3. 2020.

Dragojlo, Sasa and Xhorxhina Bami (2020): Land Swap Idea Resurfaces to Haunt Serbia-Kosovo Talks. Accessible at https://balkaninsight.com/2020/06/16/ land-swap-idea-resurfaces-to-haunt-serbia-kosovo-talks/\#: :text=Despite\%20 that $\% 2$ C 20 in $\% 201$ ast $\% 20$ three,his\%20Kosovo\%20counterpart\%2C\%20 Hashim\%20Thaci, 10. 11. 2020.

Eberhardt, Peter, Peter Flanagan, Samantha Scott, Christopher Wial and Devon Yee (2020): Not the Great Equalizer: Which Neighbourhoods Are Most Economically Vulnerable to the Coronavirus Crisis? Initiative for a Competitive Inner City. Accessible at https://icic.org/blog/not-the-great-equalizer-which-neighborhoods-are-most-economically-vulnerable-to-the-coronavirus-crisis/, 10. 11. 2020. 
Fort, Emilie (2018): Municipalities or Enclaves? How to Describe Serbian Majority Areas in Kosovo. Accessible at https://blogs.lse.ac.uk/europpblog/2018/08/13/ municipalities-or-enclaves-how-to-describe-serbian-majority-areas-in-kosovo/, 15. 10. 2019.

Freedom House (2020): Bulgaria Country Report. Accessible at https://freedomhouse.org/country/bulgaria/freedom-world/2020, 10. 11. 2020.

Goergieva, Silvia (2020): За химяди деца електронното обучение е на харти . Accessible at https://segabg.com/node/130750, 1. 7. 2020.

Krasimirov, Angel (2020): Fans break distancing rules at Bulgarian Cup final. Accessible at https://uk.reuters.com/article/uk-health-coronavirus-soccer-bulgaria/fans-break-distancing-rules-at-bulgarian-cup-final-idUKKBN24278D, 10. 11. 2020.

Matković, Gordana and Stubbs (2020): Social Protection in the Western Balkans. Responding to the Covid-19 Crisis. Friedrich Ebert Stiftung. Sarajevo: July 2020. Accessible at http://futureofthewelfarestate.org/regional-study-social-protection-in-the-western-balkans-responding-to-the-covid-19-crisis-published/, 10. 11. 2020.

Rapid Response Civic Group. Mitrovica: NGO Aktiv:2020. Accessible at NGO Aktiv - COVID19 Crisis - Active Citizens Response, 10. 11. 2020.

Shentov, Ognian and Ruslan Stefanov (2020): The Shrinking Space for Media Freedom in Southeast Europa in the Midst of Covid-19 and State of Emergency. Center for the Study of Democracy and Konrad-Adenauer-Stiftung Media Programme South East Europe. Available at https://csd.bg/publications/publication/the-shrinking-space-for-media-freedom-in-southeast-europe/, 10. 11. 2020.

Simic, Jelena (2020): Covid-19 Exacerbates Ethnic Serb Limbo in Kosovo. Accessible at https://balkaninsight.com/2020/09/30/covid-19-exacerbates-ethnic-serblimbo-in-kosovo/, 2. 10. 2020.

The Balkans in Europe Policy Advisory Group (BiEPAG) (2020): The Western Balkans in Times of the Global Pandemic. Accessible at https://biepag.eu/publications/, 2. 10. 2020.

The Impact of Covid-19 Pandemic on the Kosovo Budget. Pristina: GAP Institute: June 2020. Accessible at https://www.institutigap.org/news/2571, 10. 11. 2020.

Trupia, Francesco and Gnetiola Madhi (2021): Reforming or Reconceptualising Post-Pandemic Education in the Western Balkans? An Analysis of Albania, Kosovo and Serbia. Kosovo Foundation for Open Society. Accessible at https:// kfos.org/en/publications/95/reform-or-reconceptualization-education-Western-Balkans, 2. 10. 2020.

Walker, Shaun and Helena Smith (2020): Why Has Eastern Europe Suffered Less from Coronavirus Than the West? Accessible at https://www.theguardian.com/ world/2020/may/05/why-has-eastern-europe-suffered-less-from-coronavirusthan-the-west, 6. 5. 2020.

24Часа (2020): Ажамбазки от ВМРО: Затворете гетата навсякъде. Accessible at https:// www.24chasa.bg/novini/article/8320602, 7. 9. 2019. 